\title{
2013 TMS President Elizabeth Holm: Committed to the Core
}

Elizabeth Holm

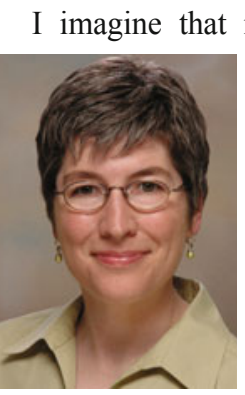

Elizabeth Holm most of my fellow TMS presidents would agree that being chosen to lead our professional society is the fulfillment of a lifetime goal. However, this is more literally true for me. You see, I have been attending professional society meetings since I was a little kid. My father, a pediatrician, was active in state and national pediatric organizations, so twice a year we traveled to events with him. Of course, my siblings and I spent our time playing in the pool, touring local attractions, or hitting the beach. But I did wonder: What was my dad doing that was better than Disneyland?

In 1989, I finally found out. As a graduate student at the University of Michigan in the infant field of computational materials science, I attended the TMS Fall Meeting in Indianapolis. The technical sessions were amazing, filled to the brim with new ideas and old wisdom, and I delighted in pairing faces to names that I had only read before. There was even a whole symposium on Simulation and Theory of Evolving Microstructures. It really was better than Disneyland.

By 1992, when I joined Sandia National Laboratories, I had become a regular at TMS meetings, always as a symposium participant. But that was about to change. At the 1993 Annual Meeting a Sandia colleague suggested (insisted!) that I attend a technical committee meeting, so I joined the Chemistry and Physics of Materials Committee. All of a sudden, I found out where all those symposia come from; they are organized by volunteer members just like me. I co-chaired my first symposium in 1995 , on a topic I wanted to learn more about. Perhaps the best part was inviting speakers whose knowledge I hoped to mine. Some of those speakers remain collaborators and friends to this day.

Well, one thing led to another, and I kept adding reasons not to go to Disneyland. I participated in technical, administrative, business, and awards activities . As TMS responded to member needs, I contributed to new initiatives, including the Integrated Computational Materials Engineering (ICME) and Women in Materials Science committees. At one point or another, I've been a member of three of our five technical division councils. And after more than 20 years, I am still discovering new facets of TMS.

Did you know that TMS is the lead society for recommending ABET program criteria? That's important to me, in my new position as a Professor in the Materials Science and Engineering Department at Carnegie Mellon University. How about the fact that TMS oversees the Professional Engineer exam question preparation? That we have a voice in the White House through a TMS fellow at the Office of Science and Technology Policy? That we provide impartial, expert opinions on questions of international importance, including materials for energy needs and ICME? That we are preparing to show the public that materials science is cool with an exhibit on Comic Book Materials Science? You will read about all these activities, and more, in JOM in the coming year.

There is one TMS initiative I want to highlight: the third goal of the TMS Strategic Plan-"Sustain and grow our core as The Minerals, Metals \& Materials Society." While this objective refers to core materials and technologies, the true core of TMS is its dedicated volunteer members - the kind who read all the way to the end of a Presidential Perspective. I am lucky to inherit TMS at a time when this core is exceptionally strong, with a great balance of activities in every area impacting our profession. My goal for my presidency is to refocus on these sustaining members and activities, to ensure that the professional society that has served them so well since 1871 remains their destination of choice for the next 142 years.

Since this column is supposed to be an introduction, I shouldn't leave you with the impression that TMS is the sole focus of my life. I am married to Dave Crockett, and although people with that name have not historically fared well in Texas, he has bravely agreed to join me at the upcoming Annual Meeting in San Antonio. My delightful daughter, Maggie, will start college this fall-by the time you read this column, I may actually know where. I have three grown step kids and a passel of step-grandkids. And in the free time I have left, I play Celtic fiddle for Irish and Scottish dance groups, can and preserve whatever fruits and vegetables come my way, knit everything from dishcloths to hoodies, and enjoy equestrian sports. And yes, I occasionally visit Disneyland. (Ask me about my Space Mountain experience!)

This month in San Antonio, I feel lucky, honored, and excited to forego walks along the Riverwalk to begin my term as TMS President. I look forward to working with each of you to sustain and grow our professional society. Thank you for this great opportunity. 